\title{
MUSINGS ON TIME TRAVEL
}

\section{An investment for the future.}

\section{BY ROBERT REED}

$\mathrm{I}$ used to be like him. I was an ignorant, prelucid beast, physically swift but weak in time. Forty years of my life was spent and lost, nothing gained but four exceptionally dull decades. But change became possible and I made the change. I found my ground and transformed my nature, becoming a statue of superchilled glass eagerly racing across the centuries.

The valley stretches before me, green and then black. Green and black.

Up the valley the beast approaches, and reaching me, he stops moving and slows his nature. I don't know how he slows himself. A temporary trick invented in recent years, presumably.

"Letmeintroducemyself," he roars.

"Slower," I say. "Quieter."

My mind speaks, my hardware lending sounds to the thoughts.

"Sorry," he says.

"Is this better?" he asks.

If I wanted conversation, it would be an improvement. But my hardware says nothing. There's no point being rude, it decides.

Not yet, at least.

Green and black. Green and black. And the beast offers his name, adding, "I respect what you're doing. You are a pioneer."

Pioneers are dead people lost to history. But I am very much not-dead.

"A brave, bold strategy," he says.

I assume that he learned my archaic dialect while preparing for this important, uncomfortable conversation. Every word feels careful. Thought out but always delivered with a self-conscious uneasy.

"You are practically a legend," he says.

"Practically a legend." That's what people tell you when they're close to forgetting you.

"And I've come here to offer you a service," he says.

Oh shit. A salesman.

I say nothing and the green valley turns black. Night comes and stars wheel, and he says, "Two hundred and fifty-three years crossed so far."

I can measure time as well as he can.

"And you aren't ten days older," he says.

No, I'm three centuries old. I just don't show it.

He smiles and says: "Like you, I think about time travel."

Here we go. The salesman's pitch.

"We're all time travellers," he says. "You're just a lot better at it than me."

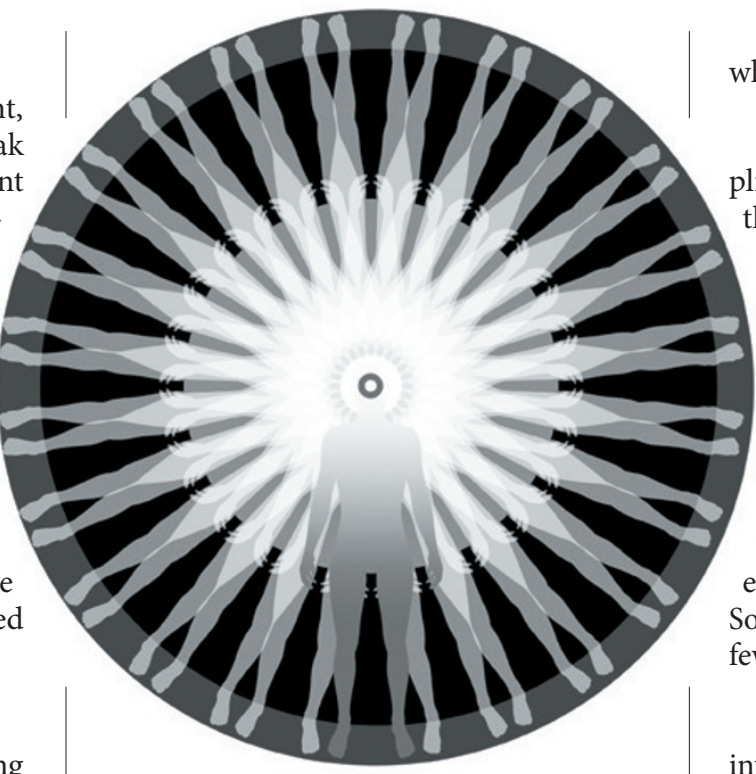

He agrees with my praise, adding: "But what if?"

I bite. "What if what?"

"If the great goals of life could be accomplished outside time. For instance, what if there was a scenario in which the entirety of your life could play out inside one cold nanosecond?"

"No," I say.

More than once.

"But you shouldn't dismiss me," he says, standing in a sudden rainstorm. "Not if the end result is a vast improvement over your present life. Which is what you did before, isn't it? You didn't enjoy your old life, sluggish and limited. So you remade yourself, accomplishing what few others would even dare attempt."

He knows his market, that's for certain.

Rain finishes with a red Sun plunging into the sea, and the world spins us through space, and I ask: "Why would I want such a life?"

Then he says, "Sir, do you know why time travel was invented, Sir?"

My hardware could ask him to leave. My AI lawyers, the best in the Solar System, could slap muscular injunctions on him. And to that end, I begin to string together the appropriate commands.

Except then he says: "Consider the first life, the simplest, tiniest cell."

Okay.

"Think what it had to do to survive," he says.

The Sun rises. A cloudy day, with rain rushing in from the ocean on my horizon.

"To survive," he says, "life had to find a complex form. And that form, the good body, had to eat. Grab energy and reproduce. But how does life get enough food? Unless you're a plant, there was never enough nourishment in one physical location. That's why animals grew legs. To graze, to hunt. But of course even a plant has to move. The algae on a rock. There isn't enough sunlight in one nanosecond to feed a little chloroplast. To thrive, the microbe has to journey through time. Which is my point: time travel was invented by our oldest ancestors. Because where life is possible, even if it is only rooted in one spectacular patch of ground, the ignorant entity still has to cross the days and seasons, just on the hope of enduring." $\rightarrow$ NATURE.COM

Follow Futures: @NatureFutures

$f$ go.nature.com/mtoodm
A salesman, yes. But interesting nonetheless.

"Interesting," is the word I offer.
"Because inside that instant, every thought will be possible. Every daydream, every creative urge. Every every everything will be laced into a single eruption of genius. And as I have been assured, that perfection won't last for an instant. Not to the person enjoying it, no. To those special few pioneers, it will seem like a euphoric blaze lasting ten billion years."

I'm not ignorant. My hardware keeps me up to date with human events and the march of technology.

This is news to me.

"Is this even remotely possible?" I ask.

The Sun rises behind me, and squinting into the blaze, he admits: "Not yet, no. The basic research has only just commenced. And even if it were possible, the projected costs would be in excess of what your trust funds could afford."

All becomes clear.

"But it will become possible," he says. "And your investments will eventually make you wealthy enough."

This is a salesman with a very long view.

"Give the idea time," he suggests.

"I will," I promise.

And with that, my new friend walks back down the valley, his long shadow growing short before he vanishes into my thoughts.

Robert Reed is the author of several hundreds stories and a few novels. He won a Hugo before it was controversial. He lives in Lincoln, Nebraska. 